\title{
The genetic aetiology of Silver-Russell syndrome
}

\author{
S Abu-Amero, D Monk, J Frost, M Preece, P Stanier, G E Moore
}

Institute of Child Health, University College London, London, UK

\section{Correspondence to:}

Professor G Moore, Institute of Child Health, University College London, 30 Guilford Street, London WC1N 1EH, UK; gmoore@ich.ucl.ac.uk

Received 10 July 2007 Revised 3 December 2007 Accepted 4 December 2007 Published Online First 21 December 2007

\begin{abstract}
Silver-Russell syndrome (SRS MIM180860) is a disorder characterised by intrauterine and/or postnatal growth restriction and typical facies. However, the clinical picture is extremely diverse due to numerous diagnostic features reflecting a heterogeneous genetic disorder. The mode of inheritance is variable with sporadic cases also being described. Maternal uniparental disomy (mUPD) of chromosome 7 accounts for $10 \%$ of SRS cases and many candidate imprinted genes on 7 have been investigated. Chromosome 11 has moved to the forefront as the key chromosome in the aetiology, with reports of methylation defects in the $\mathrm{H} 19$ imprinted domain associated with the phenotype in $35-65 \%$ of SRS patients. Methylation aberrations have been described in a number of other imprinted growth related disorders such as BeckwithWiedmann syndrome. This review discusses these recent developments as well as the previous work on chromosome 7. Other candidate genes/chromosomal regions previously investigated are tabled.
\end{abstract}

The first clinical descriptions of Silver-Russell syndrome (SRS) were published by Silver et al ${ }^{1}$ and Russell ${ }^{2}$ who independently described unrelated children characterised by low birth weight and with additional features including triangular shaped face, pointed chin and body asymmetry in a subset of patients. Since then more than 400 cases have been reported in the literature with a variable estimated incidence from 1 in 3000 to 1 in $100000 .{ }^{3}$ Throughout life, the manifestation of profound growth restriction persists and may lead to feeding difficulties with associated fasting hypoglycaemia. In general, this tends to be the main clinical problem and life expectancy appears to be unaffected by the condition. The main parental and clinical concern during infancy, therefore, is poor eating habits and much effort is expended in encouraging adequate feeding. For those children not showing catch up growth by the age of 2 years, growth hormone therapy is encouraged and is usually given daily as subcutaneous injections for up to 3 years. ${ }^{4}$ Price et $a l^{5}$ proposed that to be able to make a diagnosis of SRS, the patient must exhibit the following five key features as well as any number of the other features described in box $1^{56}$ :

1. Birth weight below or equal to $-2 \mathrm{SD}$ from population mean

2. Poor postnatal growth below or equal to $-2 \mathrm{SD}$ from the mean value at diagnosis

3. Preservation of occipitofrontal head circumference (OFC)

4. Classic facial features

5. Skeletal asymmetry.

\section{GENETIC AETIOLOGY}

SRS is a clinically and genetically heterogeneous disorder. Autosomal dominant, autosomal recessive and X-linked inheritance models have all been reported. ${ }^{7}$ Both concordant ${ }^{8}$ and discordant ${ }^{910}$ monozygotic twins for SRS have also been found. Given this complex genetic aetiology, it is not surprising that a number of different chromosomes and potential candidate genes have been implicated in the cause of SRS. Up to 2005, the most widely discussed chromosome involvement was with chromosome 7, but recent findings have shown that loci on chromosome 11 have a big part to play in the origins of this disorder. The implications of these exciting new findings are discussed in detail below.

\section{Chromosome 7}

Chromosome 7 as a candidate locus for SRS has been studied in detail after maternal uniparental disomy (mUPD) 7 was found in a subset of patients with pre- and postnatal growth restriction. ${ }^{11-14}$ It was postulated that the growth restriction might be due to growth related imprinted genes located on this chromosome.

Imprinted genes represent a very small proportion of the total gene complement, which differ from the rest in the manner of their transcriptional regulation. Unlike most genes that are active from both maternally and paternally inherited chromosomes (that is, biallelic), imprinted genes are only active from one parental allele (that is, monoallelic). For germ line imprinted genes, this is dictated in the egg or sperm. Imprinted genes are therefore regulated according to parent-of-origin, and function in a hemizygous state. An imprinted gene may be paternally expressed and maternally imprinted (silenced) or maternally expressed and paternally imprinted (silenced).

This hypothesis was elegantly demonstrated by pioneering work in the 1980s by Barton et a ${ }^{15}$ and McGrath and Solter ${ }^{16}$ who created diploid mouse embryos with either gynogenetic (completely maternal) or androgenetic (completely paternal) genomes to examine the phenotypic effect on conceptuses. Gynogenetic conceptuses produced only embryonic material with little or no placentation whereas androgenetic conceptuses displayed poor embryonic development with recognisable trophoblast tissue and yolk sacs. It was obvious from these experiments that the maternal and paternal genomes made differential contributions to fetal growth and development. This hypothesis was further defined by the creation of mouse strains with Robertsonian and reciprocal translocations to create artificial UPDs for sub-chromosomal regions. Interestingly, some chromosomes in the UPD state had no visible phenotypes whereas 
others showed profound growth related effects. ${ }^{17} 18$ One of the many cited examples is that of mice with maternal or paternal UPD for part of mouse chromosome 11, which is syntenic with human chromosome 7. Mice with mUPD11 were on average $30 \%$ smaller than their wild type littermates, independent of sex, while the pUPD11 mice were 30\% larger than their wild type littermates. ${ }^{17}$ This demonstrated a polarising epigenetic effect on the same phenotype. It is now accepted that, in general, paternally expressed genes show promotion of fetal growth whereas maternally expressed genes have a tendency to restrict fetal growth. This imprint, which effectively silences one parental copy of a gene, is epigenetic, and is reset during gametogenesis. ${ }^{19}$

The findings that maternal UPD7 in humans is associated with pre- and postnatal growth restriction, and that imprinted genes have a phenotypic dosage effect in mice, suggested chromosome 7 as a possible candidate for SRS pathogenesis. Several groups therefore screened cohorts of clinically defined SRS patients both for mUPD7 and/or imprinted gene(s) on chromosome 7 that may contribute to the observed growth disorder. ${ }^{20-22}$ UPD7 is readily detectable using polymorphic short tandem repeat (STR) microsatellite markers by polymerase chain reaction (PCR) or variable number of tandem repeat (VNTRs) by Southern blotting. Of the 98 SRS patients

\section{Box 1: Characteristics of Silver-Russell syndrome (SRS)}

\section{Physical features}

- Facial dysmorphism: classic facial features of small triangular facies, high forehead with pointed chin and down turned corners of the mouth

- Short stature persisting into adulthood

- Skeletal asymmetry

- Preservation of occipitofrontal circumference

- Clinodactyly

- Camptodactyly \pm distal arthrogryposis

- Syndactyly of second and third toes

- Hemihypertrophy

- Urogenital dysmorphism:

- Hypospadias

- Posterior urethral valves

- Inguinal hernia

\section{Clinical features}

- Birth weight $\leqslant-2$ SD from the mean. Usually followed by failure to thrive

- Poor head control during infancy due to relatively large head compared to body as well as general motor dysfunction due to lack of muscle bulk and strength

- Feeding difficulties in infancy and childhood leading to fasting hypoglycaemia

- Increased sweating during infancy

- Gastrointestinal symptoms including gastro-oesophageal reflux, oesophagitis and food aversion

- Developmental delay which may be associated with mental compromise in a subset of patients

- Delayed bone age

- Cardiac defects

- Malignancies

Information adapted from OMIM entry 180860-http://www.ncbi. nlm.nih.gov/entrez/dispomim.cgi?id $=180860 ;{ }^{5}{ }^{6}$ collectively screened by these groups, nine were found to have mUPD7 and it is now widely acknowledged that this mechanism is responsible for approximately $10 \%$ of SRS cases. As an alternative to disrupting imprinted gene expression, the hypothesis that the UPD might be uncovering a recessive allele was also tested. ${ }^{22}$ Several examples of this have been described for chromosome 7 where patients with cystic fibrosis appear to be homozygous for delta508 despite only having one carrier parent. ${ }^{11223}$ This turns out to be due to isodisomy, where the patient inherits two copies of the same chromosome from one parent while the normal chromosome is excluded. Preece et a ${ }^{22}$ therefore analysed five mUPD7 patients for common regional isodisomic inheritance using 40 polymorphic markers distributed along the length of chromosome 7 with an average distance between markers of $<10 \mathrm{cM}$. They found no common region of isodisomy among the five probands, suggesting the phenotypic effect of chromosome 7 is either due to exposure of recessive alleles for several different genes or much more likely due to a common imprinting effect. The observation of mUPD7 in SRS as a genetic aetiology appears to be an almost exclusive phenomenon as it has not yet been reported in screening of individuals with intrauterine growth restriction (IUGR) or preand/or postnatal growth restriction. ${ }^{24}$

Interestingly, Hoglund et $a^{25}$ and Pan et $a^{26}$ describe single case reports each of complete paternal isodisomy for chromosome 7 with normal growth phenotype. This contrasts sharply with the overgrowth phenotype seen in the syntenic pUPD11 mice and suggests that the human phenotype is related to maternal growth restricting genes rather than paternal growth promoting genes. However, a single case report of a boy with cystic fibrosis with complete paternal isodisomy for chromosome 7 displaying overgrowth was recently published, reopening the possibility of paternally active imprinted genes on this chromosome playing a role in growth. ${ }^{27}$ Two key candidate regions on chromosome 7 have been delineated as the most likely areas to contain the genes that may be causative factors in SRS.

\section{$7 q 32$}

Kobayashi et $a^{28}$ suggested the human equivalent of the imprinted mouse Peg1/Mest (mesoderm expressed transcript) gene as a candidate for SRS. They developed a novel subtraction-hybridisation method to isolate imprinted genes systematically. Of eight paternally expressed genes (Pegs), Peg1/ Mest was identified as the most abundantly expressed in embryos, specifically in the mesoderm. ${ }^{29}$ Mest maps to mouse proximal chromosome 6 , which shares conserved synteny with human chromosome 7q21-qter. This region contains the paternally expressed MEST gene, which was the first imprinted gene to be identified on chromosome $7 .{ }^{28}$ Based on its imprinting status and the mouse phenotype, MEST has been investigated extensively as a candidate for SRS, but sequencing and methylation studies have as yet found no evidence for an involvement. ${ }^{30}$

An SRS patient with a rare segmental mUPD for the region 7q31-qter further implicated this region to be harbouring a potential candidate gene(s) for SRS. ${ }^{31}{ }^{32}$ Recently, a case report of a girl born after assisted reproductive technology (ART) and diagnosed with SRS was investigated for methylation status of the MEST region. ${ }^{33}$ They observed partial hypermethylation of the MEST DMR and speculated that this may have some effect on this paternally expressed growth promoting gene.

Several other imprinted genes were found in the vicinity of $M E S T$, including the paternally expressed intronic transcript 
from the biallelically expressed gamma-2 COP (nonclathrincoatprotein) (COPG21T1), paternally expressed MEST1T1 (also known as PEG1-AS) and the maternally expressed carboxypeptidase A4 (CPA4) ${ }^{34}$ CPA4 has a role in cell proliferation and differentiation. ${ }^{35}$ However, no mutations were seen for $C P A 4$ in the 10 SRS patients screened or in other imprinted genes in this region. ${ }^{36}{ }^{37}$ Neighbouring genes flanking these imprinted genes were all shown to be biallelic, delineating the extent of a small imprinting cluster. ${ }^{38}$ Meanwhile, mice either targeted for mutation of the homologous Mest gene or mice with mUPD for chromosome 6 (which are equivalent to null for the paternally expressed Mest gene), result not only in IUGR and reduction in postnatal survival but also in abnormal maternal behaviour including impaired placentophagia. ${ }^{39} 40$ The latter finding provided the first evidence that normal and abnormal imprinting may also play an important role in behaviour.

\section{7p11.2-p13}

Joyce et $a l^{41}$ reported a mother and daughter with some but not all of the key features of SRS. Cytogenetic and fluorescent in situ hybridisation (FISH) established that both mother and daughter had an inverted duplication of the proximal short arm of chromosome 7 encompassing the region 7p13-p12.1. This region harbours the growth factor receptor bound protein-10 (GRB10) gene which is imprinted in an isoform and tissue specific manner. GRB10 encodes a cytoplasmic adaptor protein which may facilitate linkage of cell surface tyrosine kinase receptors, such as the insulin receptor (IR) and insulin-like growth factor-1 receptor (IGFIR) to an uncharacterised mitogenic signalling pathway, and also binds epidermal growth factor receptor (EGFR) and the platelet derived growth factor receptor.

The orthologous Grb10 gene is located on mouse chromosome 11 which is associated with the growth imprinting phenotype described by Cattanach and Kirk. ${ }^{17}$ The GRB10 gene could be considered a very strong candidate for SRS. ${ }^{42}$ Monk et a $l^{43}$ identified a maternally derived de novo duplication in a female patient with some of the classic features of SRS. The duplication involved 7p13-p11.2, encompassing GRB10 at $7 \mathrm{p} 12.2$ and the biallelically expressed insulin-like growth factor binding proteins 1 and 3 (IGFBPI and IGFBP3). ${ }^{44}$ In addition to this family, a further two maternally inherited duplications encompassing GRB10, and several chromosomal disruptions in the 7p11.2-p13 region, have also been described. ${ }^{45}$ More recently a maternally inherited duplication of 7p12-p13 in a patient with cognitive deficit without features of SRS has been reported in the literature. ${ }^{46}$ This duplication does not extend to include GRB10 and delineates an SRS critical interval of $2.2 \mathrm{Mb}$ containing only GRB10 and the biallelically expressed cordon bleu gene $(C O B L)$. Therefore the growth restriction observed is most likely due to the over-expression of the imprinted GRB10 gene.

The GRB10 gene is imprinted in a highly isoform and tissue specific manner. In both mouse and human, expression in the brain is derived from the paternal allele. In the mouse all other isoforms in embryonic and placental tissues are expressed from the maternal allele. This maternal expression is not completely conserved in the human, with only the $\gamma 1$ and $\gamma 2$ isoforms imprinted in muscle, and expression in other all tissues reported, derived from both parental alleles. ${ }^{47-49}$ Mice carrying maternally inherited targeted deletions of Grb10 show a growth phenotype identical to the phenotypes described for the pUPD11 and PatDp11 mice, consistent with an involvement in SRS. ${ }^{50}$ In total, 76 SRS patients were screened for mutations in GRB10 but no pathogenic changes were found. ${ }^{48} 51$ Arnaud et $a l^{49}$ and Monk et $a^{52}$ found no significant changes in the differentially methylated region (DMR) for GRB10 in 24 and 22 SRS patients, respectively. Therefore, despite the location and proposed function of GRB10 and its function in mice, there have not been any conclusive reports of SRS being caused by overexpression or loss of imprinting of $G R B 10$, or by gain of function coding mutations.

\section{Chromosome 11}

The $11 \mathrm{p} 15.5$ region contains two clusters of imprinted genes each regulated by its own imprinting centre region (ICR). H19 and insulin-like growth factor 2 (IGF2) are controlled by the $H 19$ differentially methylated domain (DMD), which is the telomeric ICR1, while the genes within the KCNQ1 cluster are regulated by the centromeric $K v D M R 1$ called ICR2. This region has become a key focus in the aetiology of SRS ever since the report of hypomethylation of the ICR1 in five of nine SRS patients studied by Gicquel et al. ${ }^{53}$ They hypothesised that epigenetic dysregulation of genes in the human 11 p15.5 region encompassing the telomeric ICR1 region and the more centromeric ICR2 region involved in the aetiology of Beckwith-Wiedemann syndrome (BWS) (OMIM 130650) could be genotypically and phenotypically opposite for SRS.

BWS is characterised by macroglossia, pre- and/or postnatal growth greater than the 90th centile and abdominal wall defects..$^{54}$ In addition, umbilical abnormalities and characteristic linear indentation of the earlobe are included in the diagnostic criteria. BWS patients are also at increased risk of tumours. ${ }^{55} 56$ Interestingly, these patients have large placentae that are almost twice the normal weight. ${ }^{57}$

The genetic aetiology of BWS is extremely heterogeneous with most reported cases being sporadic. In a study of 106 sporadic BWS cases, $17 \%$ were due to paternal isodisomy of the $11 \mathrm{p} 15$ region which contains the reciprocally imprinted genes IGF2 and H19 (ICR1) as well as the KCNQ1 domain (ICR2). ${ }^{58}$ As IGF2 is a potent prenatal growth factor, over-expression of IGF2 should lead to tissue hyperplasia.

Weksberg et al ${ }^{59}$ examined skin fibroblasts in five monozygotic twin pairs discordant for BWS and found loss of methylation of the maternal allele of the ICR 2 in the affected twin only. Imprinting defects of the ICR2 that result in loss of expression of the cyclin dependent kinase inhibitor 1C (CDKN1C) gene are the most common epimutation found in $50 \%$ of BWS patients. Maternally inherited coding mutations of CDKN1C have also been reported in 5\% of BWS patients. ${ }^{60}$ However, $10 \%$ of BWS patients exhibit hypermethylation of ICR1 and the promoter region, resulting in loss of expression of the non-coding $H 19$ gene and the biallelic expression of $I G F 2 .{ }^{58}$

Research into the imprinting control of this domain reveals a complicated regulatory mechanism. The ICR1 is a paternally methylated germline DMR, located 2-4 kb upstream of the H19 transcript that contains several CCCTC binding factor (CTCF) binding sites. The binding of CTCF confers ICR1 function as a methylation sensitive insulator between the multiple IGF2 promoters and enhancers located downstream of H19. On the unmethylated maternal allele, CTCF binds to form a boundary that prevents the IGF2 promoters interacting with the enhancers, whereas on the methylated paternal allele, CTCF cannot bind and the IGF2 promoters can freely associate with the enhancer to bring about expression from the paternal allele only. ${ }^{61}{ }^{62}$ Therefore any gain or loss of methylation of ICR1 will result in aberrant IGF2 expression, potentially corresponding to the opposite growth phenotypes of SRS and BWS (fig 1). 

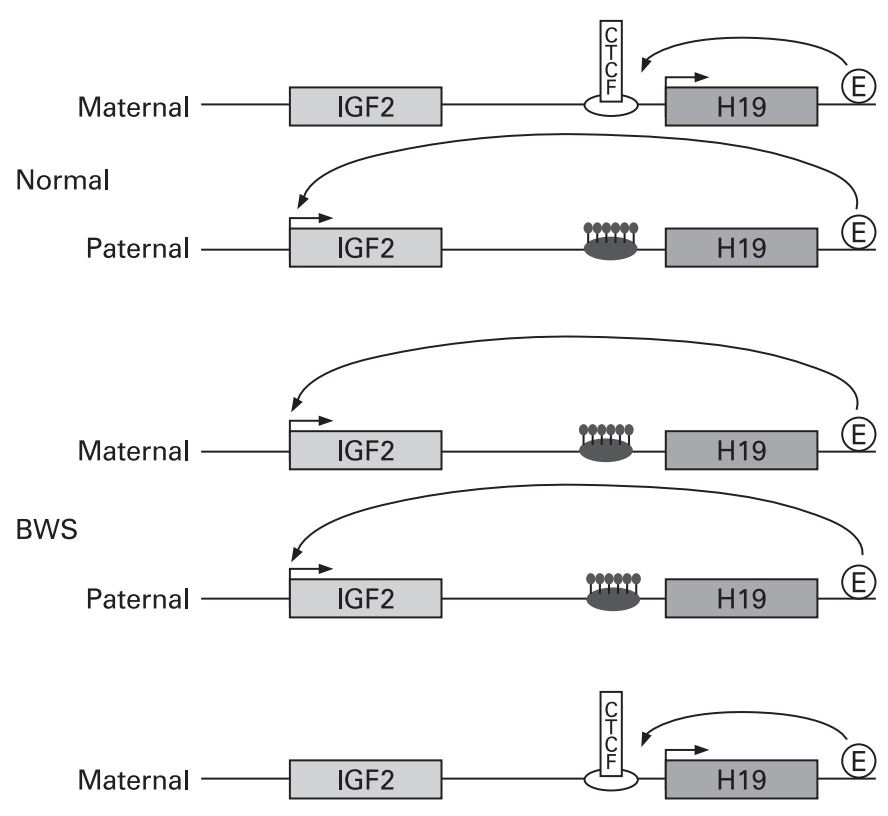

SRS

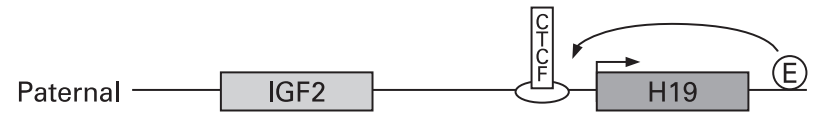

Figure 1 Role of methylation in regulation of IGF2 and H19 expression. In normal individuals, CTCF binds to the unmethylated maternal allele ICR1 which prevents IGF2 promoters interacting with enhancers and silences IGF2. On the paternal allele, CTCF is inhibited from binding to the methylated ICR1, permitting IGF2 promoter association with enhancers which results in paternal allele expression only. In Beckwith-Wiedemann syndrome (BWS) patients, hypomethylation of the ICR1 permits IGF2 promoter association with enhancers from both maternal and paternal alleles resulting in over-expression of IGF2. In Silver-Russell syndrome (SRS) patients, hypomethylation of the ICR1 prevents IGF2 promoter interactions with enhancers resulting in no expression of IGF2 from either allele.

Eggermann et $a l^{63}$ had previously described two SRS patients with maternal duplication of $11 \mathrm{p} 15$ material and, together with the observation of epigenetic defects in this region of BWS patients, prompted Gicquel et $a l^{53}$ to examine their SRS patients to see whether epigenetic defects may also explain the opposite growth phenotype. No methylation changes were seen in the centromeric ICR2 KCNQ1OT1 gene for any of their patients, but partial hypomethylation was observed in the $\mathrm{H}_{19}$ gene in lymphoblasts and fibroblasts of five SRS patients. The change was proposed to cause loss of methylation of the H19 promoter leading to biallelic $H 19$ expression, downregulation of IGF2 and hence growth restriction. The degree of hypomethylation was correlated with the severity of the phenotype. Of critical note, one of the five SRS patients is a monozygotic twin discordant for SRS. Although her non-SRS twin showed the same partial hypomethylation in her leucocytes with concomitant biallelic expression of H19, skin fibroblast from the non-SRS twin showed no methylation abnormalities. This can be explained by the shared fetal circulation of monozygotic twins in utero. The group went on to corroborate their findings with a larger cohort of 58 SRS patients where $64 \%$ of the patients showed hypomethylation of the ICR1 region, a finding not seen in any of 68 SGA patients. ${ }^{64}$

The resulting growth restriction could be caused by over expression of either $C D K N 1 C$, a known negative regulator of cell proliferation and growth, or PHLDA2, which has been found to be upregulated in IUGR babies. ${ }^{65} 60$

Netchine et $a l^{64}$ also correlated the degree of hypomethylation with the severity of the growth restriction and asymmetry as well as failure to thrive, relative macrocephaly and prominent forehead. Also of interest is that the methylation is partial and variable among individuals which may give rise to tissue mosaicism. The degree and severity of body asymmetry may be a reflection of the timing of the phenomenon postfertilisation. In addition the IGF-II serum concentrations did not appear to be altered pathologically in these individuals. ${ }^{64} 67$

It appears that the SRS patients with ICR1 methylation defects might comprise a distinct clinical cohort from the mUPD 7 patients and other idiopathic SRS cases. As early as 2001 Hannula et a ${ }^{68}$ suggested that the mUPD 7 SRS patients were phenotypically milder than others, with pre- and postnatal growth restriction, and mild or absent SRS craniofacial dysmorphology. This included slight or absent facial triangularity, absent micrognathia, absent downturned mouth corners, speech delay, poor feeding throughout childhood and excessive sweating.

The H19 methylation status of all of the patients studied to date is summarised in table 1.

A single case of SRS with maternal duplication of ICR2 has been reported recently. ${ }^{71}$ Three other patients had previously been described with maternal duplication of $11 p$ encompassing the ICR1 and ICR2 regions. All three had IUGR but only one was considered for SRS diagnosis and did not meet the criteria. ${ }^{72}$ Eggermann et a ${ }^{70}$ have compared and contrasted the mutation

Table 1 Methylation analysis of ICR1 and ICR2 in growth affected patients

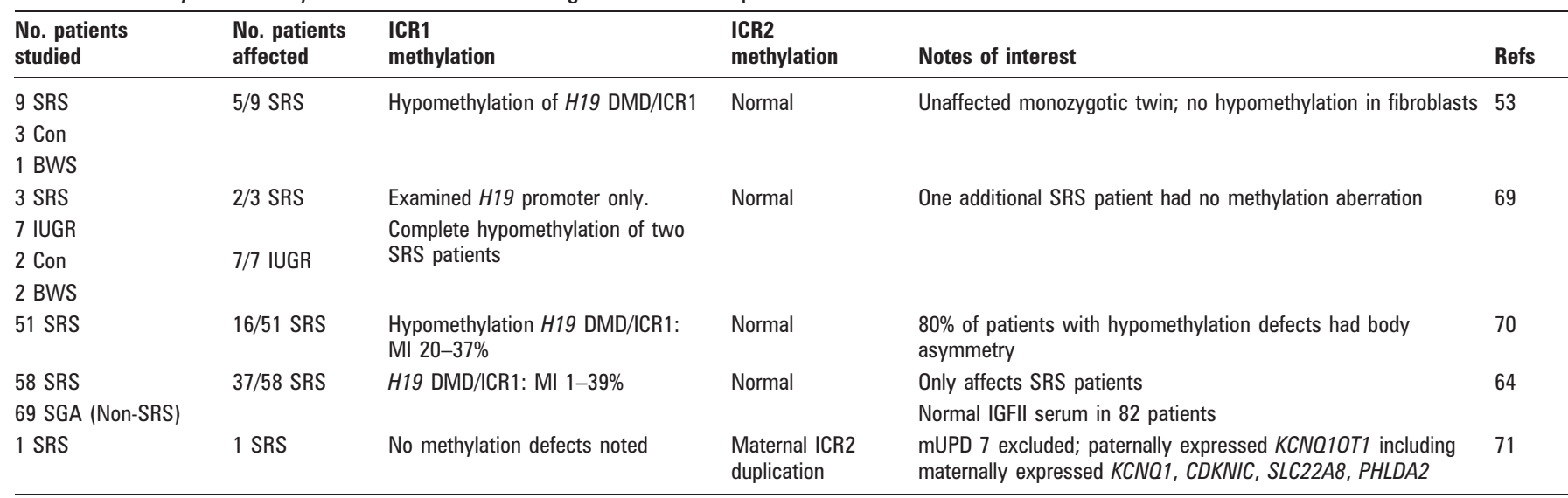


Table 2 Other chromosomes (Chr) considered as candidate loci for Silver-Russell syndrome (SRS)

\begin{tabular}{|c|c|c|c|c|c|c|}
\hline Chr & $\begin{array}{l}\text { No. } \\
\text { reports }\end{array}$ & $\begin{array}{l}\text { No. } \\
\text { patients }\end{array}$ & Genotype & Atypical features & Refs & Notes \\
\hline \multirow[t]{2}{*}{1} & \multirow[t]{2}{*}{2} & 1 & Trisomy 1q32.1-42.1 & None & 79 & \\
\hline & & 1 & Dup 1q42-qter & None & 80 & \\
\hline 8 & 1 & 1 & Del 8q11-q12 & $\begin{array}{l}\text { Microcephaly, shallow supraorbital ridges, } \\
\text { hypoplastic alae nasi }\end{array}$ & 81 & \\
\hline \multirow[t]{3}{*}{15} & \multirow[t]{3}{*}{3} & 1 & r15 & Mental retardation, cardiac defects & 82 & \multirow{3}{*}{$\begin{array}{l}\text { IGF1R coding for the IGF-1 receptor in most } \\
\text { tissues. The receptor is an important component of } \\
\text { the growth hormone IGF axis in both pre- and } \\
\text { postnatal growth. However, extensive studies of } \\
\text { IGF1R in SRS patients has failed to show any } \\
\text { mutations }^{85-87}\end{array}$} \\
\hline & & 1 & r15 (p12q26.3) & Mental retardation, microcephaly & 83 & \\
\hline & & 1 & $\begin{array}{l}\text { Trisomy7q34-qter; monosomy } \\
\text { 15q26.3-qter }\end{array}$ & Bilateral congenital glaucoma & 84 & \\
\hline \multirow[t]{3}{*}{17} & \multirow[t]{3}{*}{3} & \multirow[t]{2}{*}{1} & $t(17 ; 20)(q 25 ; q 13)$ & None & 88 & \multirow{3}{*}{$\begin{array}{l}\text { A putative candidate gene in this region is } \\
\text { chorionic somatomammotropin } 1(\mathrm{CSH} 1) \text { which } \\
\text { was deleted in two SRS patients. }{ }^{91}{ }^{92} \mathrm{Growth} \\
\text { factor receptor binding protein }(\mathrm{GRB}) 2(17 \mathrm{q} 24-25) \\
\text { and } 7(17 \mathrm{q} 21-22) \text { are also localised to this } \\
\text { breakpoint. However, Hitchins et al }{ }^{93} \text { investigated } \\
\text { CSH1, GRB2 and GRB7 in } 48 \text { non-UPD } 7 \text { SRS } \\
\text { patients with no abnormal findings }\end{array}$} \\
\hline & & & $t(1 ; 17)(q 31 ; q 25)$ & None & 89 & \\
\hline & & 1 & $\begin{array}{l}\text { Hypomethylation at } 11 \mathrm{p} 15 \\
\text { plus deletion of } \mathrm{CSH} 1\end{array}$ & None & 90 & \\
\hline \multirow[t]{3}{*}{18} & \multirow[t]{3}{*}{3} & 1 & Trisomy 18 & $\begin{array}{l}\text { Many extra features of trisomy } 18 \text { syndrome, } \\
\text { mental retardation }\end{array}$ & 94 & \\
\hline & & 1 & Trisomy 18 & None & 95 & \\
\hline & & 1 & del 18p & & 96 & \\
\hline \multirow[t]{2}{*}{$X$} & \multirow[t]{2}{*}{2} & 1 & $45 \mathrm{X}$ right side & \multirow[t]{2}{*}{ None } & 97 & \multirow{2}{*}{$\begin{array}{l}\text { Partington et } a^{99} \text { described a family with short } \\
\text { stature and abnormal pigmentation with } \\
\text { symptoms more pronounced in males suggesting } \\
\text { X-linked inheritance. Younger male siblings } \\
\text { showed classical SRS features }\end{array}$} \\
\hline & & 2 & $\begin{array}{l}45 X / 45 X X Y \text { left side } \\
47 X X Y\end{array}$ & & 98 & \\
\hline
\end{tabular}

types in BWS and SRS patients on chromosome 11 and have shown that the errors are of opposite parental origin including mutations, duplications and methylation deregulation.

There have been several recent reports of children born with SRS who had been conceived by assisted reproductive technology (ART). ${ }^{33697374}$ Two of these cases were found to have methylation defects. ${ }^{33} 69$ The ART embryo culture medium is a cocktail of growth factors which could conceivably have an effect on methylation of the embryo and hence its growth potential. ${ }^{74}$ Certainly studies on in vitro culture conditions on mice pre-implantation embryos have demonstrated long term physiological, neurodevelopmental and behavioural effects. ${ }^{75} 76$ Some of these changes may be due to the observed changes in mRNA expression of imprinted genes which are particularly vulnerable during the blastocyst stage. ${ }^{75} 77$ Although ART is generally considered safe, babies with low birth weight are over represented in this population of births, as well as children with BWS and Angelman syndrome (AS) caused by imprinting defects, and it is therefore of clinical significance to determine the optimal culture conditions for future ART progeny. This may be especially important when culture media contains methyl donors which may influence methylation and imprinting. There is also the consideration that ART is performed on patients with fertility problems which could carry a higher risk of passing on aberrantly imprinted genes to their offspring. Kobayashi et $a l^{78}$ recently described abnormal paternal methylation imprints (14.5\%) and abnormal maternal imprints $(20.6 \%)$ in oligospermic men.

\section{Other chromosomes}

Apart from chromosomes 7 and 11, six other chromosomes have been associated with the SRS phenotype (table 2). In some instances the patients described have had additional or atypical features.

\section{CONCLUSION}

It is now well established that $10 \%$ of SRS patients have mUPD for chromosome 7 and up to $50 \%$ have methylation defects in the imprinted domain on chromosome 11p15. This still leaves at least $40 \%$ of SRS patients with an unknown genetic aetiology. This may be explained by patient ascertainment, where many of the diagnostic criteria are shared with other syndromes. Clinicians generally agree that there are both SRS patients and SRS-like patients with a grey area between. It may be that the diagnostic criteria need to be tightened to ensure that the classical cases are identified and separated from the non-classical cases. It will be useful to make a detailed comparison of the clinical features of all SRS patients in order to identify whether the patients can be further categorised. For example, this might include those with and without limb asymmetry and to correlate genetic aetiologies with specific symptoms. For such a genetically diverse syndrome it is still conceivable that multiple genetic defects per patient could also contribute to the final phenotype.

Epigenetics is an exciting field and one which will undoubtedly prove vital in explaining many more syndromes and diseases. Various forms of cancer have for some time been linked to epigenetics, but conditions affecting neurology, behaviour and psychopathology such as schizophrenia and Alzheimer's disease have recently also been suggested to have epigenetic components. ${ }^{100} 101$ Furthermore, the finding that diet and environment can influence epigenetic outcome, both in utero and throughout life, makes for a challenging but promising field of study. ${ }^{102}{ }^{103}$ It is clear that epigenetics plays an important role in fetal growth and development but the full understanding of the mechanisms and their effect on gene function is yet to be elucidated, particularly for the benefit of clinical application. Human epigenetic models such as SRS will continue to aid us in this pursuit. 
Acknowledgements: The authors wish to thank all patients and families who have participated in our research and are grateful to SPARKS, WellBeing of Women, March of Dimes, Medical Research Council and the Wellcome Trust for their generous support. SAA is a Wellbeing of Women fellow, DM is a March of Dimes fellow, and JF is a MRC, PhD student.

Competing interests: None declared.

\section{REFERENCES}

1. Silver HK, Kiyasu W, George J, Deamer WC. Syndrome of congenital hemihypertrophy, shortness of stature, and elevated urinary gonadotropins. Pediatrics 1953;12:368-76.

2. Russell A. A syndrome of intra-uterine-dwarfism recognizable at birth with craniofacial dysostosis, disproportionate short arms, and other anomalies (5 examples). Proc $R$ Soc Med 1954;47:1040-4.

3. Wetterau LA, Prakash-Cheng A. eMedicine.com, Silver-Russell Syndrome.

4. Kamp GA, Mul D, Waelkens JJ, Jansen M, Delemarre-van de Waal HA, VerhoevenWind L, Frolich M, Oostdijk W, Wit JM. A randomized controlled trial of three years growth hormone and gonadotropin-releasing hormone agonist treatment in children with idiopathic short stature and intrauterine growth retardation. J Clin Endocrinol Metab 2001;86:2969-75

5. Price SM, Stanhope R, Garrett C, Preece MA, Trembath RC. The spectrum of Silver-Russell syndrome: a clinical and molecular genetic study and new diagnostic criteria. J Med Genet 1999;36:837-42.

6. Anderson J, Viskochil D, O'Gorman M, Gonzales C. Gastrointestinal complications of Russell-Silver syndrome: a pilot study. Am J Med Genet 2002;113:15-9.

7. Hitchins MP, Stanier P, Preece MA, Moore GE. Silver-Russell syndrome: a dissection of the genetic aetiology and candidate chromosomal regions. J Med Genet 2001;38:810-9.

8. Rimoin DL. The Silver syndrome in twins. Birth Defects Orig Art Ser 1969;V(2):1837.

9. Nyhan WL, Sakati NO. Silver syndrome: Silver-Russell syndrome, Russell-Silver syndrome. In: Genetic and malformation syndromes in clinical medicine. Chicago: Year Book Medical Publishing, 1976:298-300

10. Samn M, Lewis K, Blumberg B. Monozygotic twins discordant for the Russell-Silver syndrome. Am J Med Genet 1990;37:543-5.

11. Spence JE, Perciaccante RG, Greig GM, Willard HF, Ledbetter DH, Hejtmancik JF, Pollack MS, O'Brien WE, Beaudet AL. Uniparental disomy as a mechanism for human genetic disease. Am J Hum Genet 1988;42:217-26.

12. Voss R, Ben-Simon E, Avital A, Godfrey S, Zlotogora J, Dagan J, Tikochinski Y, Hillel J. Isodisomy of chromosome 7 in a patient with cystic fibrosis: could uniparental disomy be common in humans? Am J Hum Genet 1989;45:373-80.

13. Spotila LD, Sereda L, Prockop DJ. Partial isodisomy for maternal chromosome 7 and short stature in an individual with a mutation at the COL1A2 locus. Am J Hum Genet 1992;51:1396-405.

14. Eggerding FA, Schonberg SA, Chehab FF, Norton ME, Cox VA, Epstein CJ. Uniparental isodisomy for paternal $7 p$ and maternal $7 q$ in a child with growth retardation. Am J Hum Genet 1994;55:253-65.

15. Barton SC, Surani MA, Norris ML. Role of paternal and maternal genomes in mouse development. Nature 1984;311:374-6.

16. McGrath J, Solter D. Completion of mouse embryogenesis requires both maternal and paternal genomes. Cell 1984;37:179-83.

17. Cattanach BM, Kirk M. Differential activity of maternally and paternally derived chromosome regions in mice. Nature 1985;315:496-8.

18. Searle AG, Beechey CV. Genome imprinting phenomena on mouse chromosome 7. Genet Res 1990;56:237-44.

19. Murphy SK, Jirtle RL. Imprinting evolution and the price of silence. Bioessays 2003;25:577-88.

20. Kotzot D, Schmitt S, Bernasconi F, Robinson WP, Lurie IW, llyina H, Mehes K, Hamel BCJ, Otten BJ, Hergersberg M, Werder E, Schoenle E, Schinzel A. Uniparental disomy 7 in Silver-Russell syndrome and primordial growth retardation. Hum Molec Genet 1995:4:583-7.

21. Eggermann T, Wollmann HA, Kuner R, Eggermann K, Enders H, Kaiser P, Ranke MB. Molecular studies in 37 Silver-Russell syndrome patients: frequency and etiology of uniparental disomy. Hum Genet 1997;100:415-9.

22. Preece MA, Price SM, Davies V, Clough L, Stanier P, Trembath RC, Moore GE. Maternal uniparental disomy 7 in Silver-Russell syndrome. J Med Genet 1997;34:69 .

23. Reboul MP, Tandonnet O, Biteau N, Belet-de Putter C, Rebouissoux L, Moradkhani K, Vu PY, Saura R, Arveiler B, Lacombe D, Taine L, Iron A. Mosaic maternal uniparental isodisomy for chromosome 7q21-qter. Clin Genet 2006;70:207-13

24. Hannula K, Lipsanen-Nyman M, Kristo P, Kaitila I, Simola KO, Lenko HL, Tapanainen P, Holmberg C, Kere J. Genetic screening for maternal uniparental disomy of chromosome 7 in prenatal and postnatal growth retardation of unknown cause. Pediatrics 2002;109:441-8.

25. Hoglund $\mathbf{P}$, Holmberg $\mathrm{C}$, dela Chapelle A, Kere J. Paternal isodisomy for chromosome 7 is compatible with normal growth and development in a patient with congenital chloride diarrhea. Am J Hum Genet 1994;55:747-52.

26. Pan Y, McCaskill CD, Thompson KH, Hicks J, Casey B, Shaffer LG, Craigen WJ. Paternal uniparental disomy of chromosome 7 associated with complete situs inversus and immotile cilia. Am J Hum Genet 1998;62:1551-5.
27. Fares F, David M, Lerner A, Diukman R, Lerer I, Abeliovich D, Rivlin J. Paternal isodisomy of chromosome 7 with cystic fibrosis and overgrowth. Am J Med Genet $A$ 2006;140:1785-8.

28. Kobayashi S, Kohda T, Miyoshi N, Kuroiwa Y, Aisaka K, Tsutsumi 0, Kaneko-Ishino $\mathrm{T}$, Ishino F. Human PEG1/MEST, an imprinted gene on chromosome 7. Hum Mol Genet 1997;6:781-6.

29. Kaneko-Ishino T, Kuroiwa Y, Miyoshi N, Kohda T, Suzuki R, Yokoyama M, Viville S, Barton SC, Ishino F, Surani MA. Peg 1/Mest imprinted gene on chromosome 6 identified by cDNA subtraction hybridization. Nat Genet 1995;11:52-9.

30. Riesewijk AM, Blagitko N, Schinzel AA, Hu L, Schulz U, Hamel BC, Ropers HH, Kalscheuer VM. Evidence against a major role of PEG 1/MEST in Silver-Russell syndrome. Eur J Hum Genet 1998;6:114-20.

31. Hannula K, Lipsanen-Nyman M, Kontiokari T, Kere J. A narrow segment of maternal uniparental disomy of chromosome 7q31-qter in Silver-Russell syndrome delimits a candidate gene region. Am J Hum Genet 2001;68:247-53.

32. Eggermann T, Mergenthaler S, Eggermann K, Ranke MB, Wollmann HA. Segmental uniparental disomy of 7q31-qter is rare in Silver-Russell syndrome. Clin Genet 2001;60:395-6.

33. Kagami M, Nagai T, Fukami M, Yamazawa K, Ogata T. Silver-Russell syndrome in a girl born after in vitro fertilization: partial hypermethylation at the differentially methylated region of PEG1/MEST. J Assist Reprod Genet 2007:24:131-6.

34. Nakabayashi K, Bentley L, Hitchins MP, Mitsuya K, Meguro M, Minagawa S, Bamforth JS, Stanier P, Preece M, Weksberg R, Oshimura M, Moore GE, Scherer SW. Identification and characterization of an imprinted antisense RNA (MESTIT1) in the human MEST locus on chromosome 7q32. Hum Mol Genet 2002;11:1743-56.

35. Bentley L, Nakabayashi K, Monk D, Beechey C, Peters J, Birjandi Z, Khayat FE, Patel M, Preece MA, Stanier P, Scherer SW, Moore GE. The imprinted region on human chromosome 7q32 extends to the carboxypeptidase A gene cluster: an imprinted candidate for Silver-Russell syndrome. J Med Genet 2003;40:249-56

36. Kayashima T, Yamasaki K, Yamada T, Sakai H, Miwa N, Ohta T, Yoshiura K, Matsumoto N, Nakane Y, Kanetake H, Ishino F, Niikawa N, Kishino T. The novel imprinted carboxypeptidase A4 gene (CPA4) in the 7q32 imprinting domain. Hum Genet 2003:112:220-6.

37. Meyer E, Wollmann HA, Eggermann T. Searching for genomic variants in the MESTIT1 transcript in Silver-Russell syndrome patients. J Med Genet 2003;40:e65

38. Yamada T, Mitsuya K, Kayashima T, Yamasaki K, Ohta T, Yoshiura K, Matsumoto N, Yamada H, Minakami H, Oshimura M, Niikawa N, Kishino T. Imprinting analysis of 10 genes and/or transcripts in a 1.5-Mb MEST-flanking region at human chromosome 7q32. Genomics 2004;83:402-12.

39. Lefebvre L, Viville S, Barton SC, Ishino F, Keverne EB, Surani MA. Abnormal maternal behaviour and growth retardation associated with loss of the imprinted gene Mest. Nat Genet 1998;20:163-9.

40. Beechey CV. Peg1/MEST locates distal to the currently defined imprinting region on mouse proximal chromosome 6 and identifies a new imprinting region affecting growth. Cytogenet Cell Genet 2000;90:309-14.

41. Joyce CA, Sharp A, Walker JM, Bullman H, Temple IK. Duplication of 7p12.1-p13 including GRB10 and IGFBP1, in a mother and daughter with features of SilverRussell syndrome. Hum Genet 1999;105:273-80.

42. Miyoshi N, Kuroiwa Y, Kohda T, Shitara H, Yonekawa H, Kawabe T, Hasegawa H, Barton, SC, Surani MA, Kaneko-Ishino T, Ishino F. Identification of the Meg1/Grb10 imprinted gene on mouse proximal chromosome 11, a candidate for the SilverRussell syndrome gene. Proc Natl Acad Sci 1998;95:1102-7.

43. Monk D, Wakeling EL, Proud V, Hitchins M, Abu-Amero SN, Stanier P, Preece MA Moore GE. Duplication of 7p11.2-p13, including GRB10, in Silver-Russell syndrome. Am J Hum Genet 2000;66:36-46.

44. Wakeling EL, Hitchins MP, Abu-Amero SN, Stanier, P, Moore GE, Preece MA Biallelic expression of IGFBP1 and IGFBP3, two candidate genes for the SilverRussell syndrome. J Med Genet 2000;37:65-7.

45. Monk D, Bentley L, Hitchins M, Myler RA, Clayton-Smith J, Ismail S, Price SM, Preece MA, Stanier P, Moore GE. Chromosome 7p disruptions in Silver Russell syndrome: delineating an imprinted candidate gene region. Hum Genet 2002;111:376-87

46. Leach NT, Chudoba I, Stewart TV, Holmes B, Weremowicz S. Maternally inherited duplication of chromosome 7, dup(7)(p11.2p12), associated with mild cognitive deficit without features of Silver-Russell syndrome. Am J Med Genet $A$ 2007; 143:1489-93.

47. Blagitko N, Mergenthaler S, Schulz U, Wollmann HA, Craigen W, Eggermann T, Ropers $\mathrm{HH}$, Kalscheuer VM. Human GRB10 is imprinted and expressed from the paternal and maternal allele in a highly tissue- and isoform- specific fashion. Hum Mol Genet 2000;9:1587-95.

48. Hitchins MP, Monk D, Bell GM, Ali Z, Preece MA, Stanier P, Moore GE. Maternal repression of the human GRB10 gene in the developing central nervous system; evaluation of the role for GRB10 in Silver-Russell syndrome. Eu J Hum Genet 2001;9:82-90.

49. Arnaud P, Monk D, Hitchins M, Gordon E, Dean W, Beechey CV, Peters J, Craigen W, Preece M, Stanier P, Moore GE, Kelsey G. Conserved methylation imprints in the human and mouse GRB10 genes with divergent allelic expression suggests differential reading of the same mark. Hum Mol Genet 2003;12:1005-19.

50. Charalambous M, Smith FM, Bennett WR, Crewe TE, MacKenzie F, Ward A. Disruption of the imprinted Grb10 gene leads to disproportionate overgrowth by an Igf2-independent mechanism. Proc Natl Acad Sci USA 2003;100:8292-7. 
51. Yoshihashi H, Maeyama K, Kosaki R, Ogata T, Tsukahara M, Goto Y, Hata J, Matsuo N, Smith RJ, Kosaki K. Imprinting of human GRB10 and its mutations in two patients with Russell-Silver syndrome. Am J Hum Genet 2000;67:476-82.

52. Monk D, Smith R, Arnaud P, Preece MA, Stanier P, Beechey CV, Peters J, Kelsey G, Moore GE. Imprinted methylation profiles for proximal mouse chromosomes 11 and 7 as revealed by methylation-sensitive representational difference analysis. Mamm Genom 2003;14:805-16.

53. Gicquel C, Rossignol S, Cabrol S, Houang M, Steunou V, Barbu V, Danton F, Thibaud N, Le Merrer M, Burglen L, Bertrand AM, Netchine I, Le Bouc Y. Epimutation of the telomeric imprinting center region on chromosome $11 \mathrm{p} 15$ in Silver-Russell syndrome. Nat Genet 2005;37:1003-7.

54. Elliott M, Bayly R, Cole T, Temple IK, Maher ER. Clinical features and natural history of Beckwith-Wiedemann syndrome: presentation of 74 new cases. Clin Genet 1994;46:168-74.

55. Sotelo-Avila C, Gonzalez-Crussi F, Fowler JW. Complete and incomplete forms of Beckwith-Wiedemann syndrome: their oncogenic potential. J Pediatr 1980;96:47-50.

56. Wiedemann HR. Tumours and hemihypertrophy associated with WiedemannBeckwith syndrome. Europ J Pediat 1983:141:129.

57. Weng EY, Moeschler JB, Graham JM Jr. Longitudinal observations on 15 children with Wiedemann-Beckwith syndrome. Am J Med Genet 1995;56:366-73.

58. Catchpoole D, Lam WW, Valler D, Temple IK, Joyce JA, Reik W, Schofield PN, Maher ER. Epigenetic modification and uniparental inheritance of H19 in BeckwithWiedemann syndrome. J Med Genet 1997;34:353-9.

59. Weksberg R, Shuman C, Caluseriu O, Smith AC, Fei YL, Nishikawa J, Stockley TL, Best L, Chitayat D, Olney A, Ives E, Schneider A, Bestor TH, Li M, Sadowski P, Squire J. Discordant KCNQ10T1 imprinting in sets of monozygotic twins discordant for Beckwith-Wiedemann syndrome. Hum Mol Genet 2002;11:1317-25.

60. Maher ER, Reik W. Beckwith-Weidemann syndrome: imprinting in clusters revisited. J Clin Invest 2000;105:247-52.

61. Hark AT, Schoenherr CJ, Katz DJ, Ingram RS, Levorse JM, Tilghman SM. CTCF mediates methylation-sensitive enhancer-blocking activity at the H19/lgf2 locus. Nature 2000:405:486-9.

62. Bell AC, Felsenfeld G. Methylation of a CTCF-dependent boundary controls imprinted expression of the Igf2 gene. Nature 2000:405:482-5.

63. Eggermann T, Meyer E, Obermann C, Heil I, Schuler H, Ranke MB, Eggermann K, Wollmann HA. Is maternal duplication of $11 \mathrm{p} 15$ associated with Silver-Russell syndrome? J Med Genet 2005;42:e26.

64. Netchine I, Rossignol S, Dufourg MN, Azzi S, Rousseau A, Perin L, Houang M, Steunou V, Esteva B, Thibaud N, Raux Demay MC, Danton F, Petriczko E, Bertrand AM, Heinrichs C, Carel JC, Loeuille GA, Pinto G, Jacquemont ML, Gicquel C, Cabrol S, Le Bouc Y. 11 p15 ICR1 imprinting center region 1 loss of methylation is a common and specific cause of typical Russell-Silver syndrome: clinical scoring system and epigenetic-phenotypic correlations. J Clin Endocrinol Metab 2007;92:3148-52.

65. McMinn J, Wei M, Schupf N, Cusmai J, Johnson EB, Smith AC, Weksberg R, Thaker HM, Tycko B. Unbalanced placental expression of imprinted genes in human intrauterine growth restriction. Placenta 2006;27:540-9.

66. Apostolidou S, Abu-Amero S, O’Donoghue K, Frost J, Olofsdottir O, Chavele KM, Whittaker JC, Loughna P, Stanier P, Moore GE. Elevated maternal expression of the imprinted PHLDA2 gene is associated with low birth weight. J Mol Med 2007:85:379-87.

67. Binder G, Seidel A-K, Weber K, Haase M, Wollmann HA, Ranke MB, Eggermann T. IGF-II serum levels are normal in children with Silver-Russell syndrome who frequently carry epimutations at the IGF2 locus. J Clin Endocrinol Metab 2006;91:4709-12.

68. Hannula K, Kere J, Pirinen S, Holmberg C, Lipsanen-Nyman M. Do patients with maternal uniparental disomy for chromosome 7 have a distinct mild Silver-russell phenotype? J Med Genet 2001;38:273-8.

69. Bliek J, Terhal P, van den Bogaard MJ, Maas S, Hamel B, Salieb-Beugelaar G, Simon M, Letteboer T, van der Smagt J, Kroes H, Mannens M. Hypomethylation of the $\mathrm{H} 19$ gene causes not only Silver-Russell Syndrome (SRS) but also isolated asymmetry or an SRS-like phenotype. Am J Hum Genet 2006;78:604-14.

70. Eggermann T, Schonherr N, Meyer E, Obermann C, Mavany M, Eggermann K, Ranke MB, Wollmann HA. Epigenetic mutations in 11 p15 in Silver-Russell syndrome are restricted to the telomeric imprinting domain. J Med Genet 2006;43:615-6.

71. Schonherr N, Meyer E, Roos A, Schmidt A, Wollmann HA, Eggermann T. The centromeric $11 \mathrm{p} 15$ imprinting centre is also involved in Silver-Russell syndrome. J Med Genet 2007:44:59-63.

72. Fisher AM, Thomas NS, Cockwell A, Stecko 0, Kerr B, Temple IK, Clayton P. Duplications of chromosome 11 p15 of maternal origin result in a phenotype that includes growth retardation. Hum Genet 2002;111:290-6.

73. Kallen B, Finnstrom O, Nygren KG, Olausson PO. In vitro fertilization (IVF) in Sweden: risk for congenital malformations after different IVF methods. Birth Defects Res A Clin Mol Teratol 2005;73:162-9.

74. Svensson J, Björnståhl A, Ivarsson SA. Increased risk of Silver-Russell syndrome after in vitro fertilization? Acta Paediatr 2005;94:1163-5.

75. Maher ER. Imprinting and assisted reproductive technology. Hum Mol Genet 2005;14 spec No 1:R133-8.

76. Ecker DJ, Stein P, Xu Z, Williams CJ, Kopf GS, Bilker WB, Abel T, Schultz RM. Long-term effects of culture of preimplantation mouse embryos on behavior. Proc Natl Acad Sci USA 2004;101:1595-600.
77. Fernandez-Gonzalez R, Moreira P, Bilbao A, Jimenez A, Perez-Crespo M, Ramirez MA, Rodriguez De Fonseca F, Pintado B, Gutierrez-Adan A. Long-term effect of in vitro culture of mouse embryos with serum on mRNA expression of imprinting genes, development, and behavior. Proc Natl Acad Sci USA 2004;101:5880-5.

78. Kobayashi H, Sato A, Otsu E, Hiura H, Tomatsu C, Utsunomiya T, Sasaki H, Yaegashi N, Arima T. Abberant DNA methylation of imprinted loci in sperm from oligospermic patients. Hum Mol Genet 2007;16:2542-51.

79. Van Haelst MM, Eussen HJ, Visscher F, de Ruijter JL, Drop SL, Lindhout D, Wouters $\mathrm{CH}$, Govaerts LC. Silver-Russell phenotype in a patient with pure trisomy 1q32.1-q42.1: further delineation of the pure 1q trisomy syndrome. J Med Genet 2002:39:582-5.

80. Kennerknecht I, Barbi G, Rodens K. Dup(1q)(q42-qter) syndrome: case report and review of the literature. Hum Genet 1993;47:1157-60.

81. Schinzel AA, Robinson WP, Blinkert F, Fanconi A. An interstitial deletion of proximal $8 q(q 11-q 13)$ in a girl with Silver-Russell syndrome like features. Clin Dysmorphol 1994;3:63-9.

82. Wilson GN, Sauder SE, Bush M, Beitins IZ. Phenotypic delineation of ring chromosome 15 and Russell-Silver syndromes. J Med Genet 1985;22:233-6.

83. Tamura T, Tohma T, Ohta T, Soejima H, Harada N, Abe K, Nïkawa N. Ring chromosome 15 involving deletion of the insulin-like growth factor 1 receptor gene in a patient with features of Silver-Russell syndrome. Clin Dysmorphol 1993;2:106-13.

84. Kato R, Kishibayashi J, Shimokawa O, Harada N, Niikawa N, Matsumoto N. Congenital glaucoma and Silver-Russell phenotype associated with partial trisomy 7q and monosomy 15q. Am J Med Genet 2001;104:319-22.

85. Rogan PK, Seip JR, Driscoll DJ, Papenhausen PR, Johnson VP, Raskin S, Woodward AL, Butler MG. Distinct 15q genotypes in Russell-Silver and ring 15 syndromes. Am J Med Genet 1996;62:10-5.

86. Abu-Amero S, Price S, Wakeling E, Stanier P, Trembath R, Preece MA, Moore GE. Lack of hemizygosity for the insulin-like growth factor I receptor gene in a quantitative study of 33 Silver Russell syndrome probands and their families. Eur J Hum Genet 1997:5:235-41.

87. Binder G, Mavridou K, Wollmann HA, Eggermann T, Ranke MB. Screening for insulin-like growth factor-I receptor mutations in patients with Silver-Russell syndrome. J Pediatr Endocrinol Metab 2002;15:1167-71.

88. Ramirez-Duenas ML, Medina C, Ocampo-Campos R, Rivera H. Severe SilverRussell syndrome and translocation (17;20) (q25;q13). Clin Genet 1992;41:51-3.

89. Midro AT, Debek K, Sawicka A, Marcinkiewicz D, Rogowska M. Second observation of Silver-Russell (sic) syndrome in a carrier of a reciprocal translocation with one breakpoint at site 17q25. Clin Genet 1993;44:53-5.

90. Eggermann T, Schonherr N, Eggermann K, Wollmann H. Hypomethylation in the $11 p 15$ telomeric imprinting domain in a patient with Silver-Russell syndrome with a CSH1 deletion (17q24) renders a functional role of this alteration unlikely. J Med Genet 2007:44:e77.

91. Eggermann T, Eggermann K, Mergenthaler S, Kuner R, Kaiser P, Ranke MB, Wollmann HA. Paternally inherited deletion of CSH1 in a patient with Silver-Russell syndrome. J Med Genet 1998;35:784-6.

92. Prager S, Wollmann HA, Mergenthaler S, Mavany M, Eggermann K, Ranke MB, Eggermann T. Characterisation of genomic variants in CSH1 and GH2, two candidate genes for Silver-Russell syndrome in 17q24-q25. Genet Test 2003;7:259-63.

93. Hitchins MP, Abu-Amero S, Apostolidou S, Monk D, Stanier, Preece MA, Moore GE. Investigation of the GRB2, GRB7 and CSH1 genes as candidates for the SilverRussell syndrome (SRS) on chromosome 17q. J Med Genet 2002;39:e13.

94. Punnett HH, Kistenmacher ML, Pileggi AJ. The Russell Silver syndrome? Or trisomy 18? Pediatrics 1973;52:756-7.

95. Chauvel PJ, Moore CM, Haslam RH. Trisomy 18 mosaicism with features of Russell-Silver syndrome. Dev Med Child Neurol 1975;17:220-4.

96. Christensen MF, Nielsen J. Deletion short arm 18 and Silver-Russell. Acta Paediatr Scand 1978;67:101-3

97. Li CC, Chodirker BN, Dawson AJ, Chudley AC. Severe hemihypotrophy in a female infant with mosaic Turner syndrome: a variant of Russell-Silver syndrome? Clin Dysmorphol 2004;13:95-8.

98. Arico M, Colombo A, Maserati E, Pasquali F, Burgio GR. The 47, XXY karyotype and unrelated malformative patterns: an unusual association. Helv Paediatr Acta 1987:42:457-61

99. Partington MW. X-linked short stature with skin pigmentation: evidence for heterogeneity of the Russell-Silver syndrome. Clin Genet 1986:29:151-6.

100. Wolf JB, Hager R. A maternal-offspring co-adaptation theory for the evolution of genomic imprinting. PLoS Biol 2006; 4:e380.

101. Van Vliet J, Oates NA, Whitelaw E. Epigenetic mechanisms in the context of complex diseases. Cell Mol Life Sci 2007;64:1531-8.

102. Fraga MF, Ballestar E, Paz MF, Ropero S, Setien F, Ballestar ML, Heine-Suñer D, Cigudosa C, Urioste M, Benitez J, Boix-Chornet M, Sanchez-Aguilera A, Ling C, Carlsson E, Poulsen P, Vaag A, Stephan Z, Spector TD, Wu Y-Z, Plass C, Esteller M. Epigenetic differences arise during the lifetime of monozygotic twins. Proc Natl Acad Sci USA 2005;102:10604-9.

103. Dolinoy DC, Weidman JR, Waterland RA, Jirtle RL. Maternal genistein alters coat color and protects Avy mouse offspring from obesity by modifying the fetal epigenome. Environ Health Perspect 2006;114:567-72 